\title{
Effect of Multi-Walled Carbon Nanotubes on MUC5AC and MUC5B Expression in Airway Epithelial Cells
}

\author{
Ji Hoon Ahn ${ }^{1}$, Hyeong Geun Kim ${ }^{1}$, Bo Hyeon Seo ${ }^{1}$, Yoon Seok Choi ${ }^{1}$, \\ Si-Youn Song ${ }^{1}$, Chang Hoon Bae ${ }^{1}$, and Yong-Dae Kim ${ }^{1,2}$ \\ ${ }^{I}$ Department of Otorhinolaryngology-Head and Neck Surgery, College of Medicine, Yeungnam University, Daegu; and \\ ${ }^{2}$ Regional Center for Respiratory Diseases, Yeungnam University Medical Center, Daegu, Korea
}

\section{호흡기 상피세포에서 MUC5AC와 MUC5B 발현에 대한 다중벽 탄소나노튜브의 효과}

안지훈 $^{1} \cdot$ 김형근 $^{1} \cdot$ 서보현 ${ }^{1}$ 최윤석 ${ }^{1} \cdot$ 송시연 $^{1} \cdot$ 배창훈 $^{1} \cdot$ 김용대 $^{1,2}$

영남대학교 의과대학 이비인후-두경부외과학교실, ${ }^{1}$ 영남대학교병원 권역 호흡기 전문질환센터 ${ }^{2}$

Received March 25, 2015

Revised May 8, 2015

Accepted May 17, 2015

Address for correspondence

Yong-Dae Kim, MD, PhD

Department of Otorhinolaryngology-

Head and Neck Surgery,

College of Medicine,

Yeungnam University,

170 Hyeonchung-ro, Nam-gu,

Daegu 705-703, Korea

Tel $+82-53-620-3781$

Fax $+82-53-628-7884$

E-mail ydkim@med.yu.ac.kr
Background and Objectives Multi-walled carbon nanotubes (MWCNT) are one of the most commonly used nanomaterials to date. Recent studies have demonstrated that MWCNT increase immune response and allergic inflammation in airway epithelial cells. However, the effects of MWCNT on mucin in human airway epithelial cells have not been reported. Therefore, in the present study, the effect of MWCNT on MUC16, MUC5AC, and MUC5B expressions were investigated in human airway epithelial cells.

Subjects and Method In mucin-producing human NCI-H292 airway epithelial cells and primary cultures of normal nasal epithelial cells, the effects of MWCNT on MUC16, MUC5AC, and MUC5B expression were analyzed by reverse transcription polymerase chain reaction, real-time polymerase chain reaction, and enzyme-linked immunosorbent assay.

Results In human NCI-H292 airway epithelial cells, MWCNT significantly induced the expression MUC5AC and MUC5B mRNA and the production of MUC5AC and MUC5B protein. However, MWCNT did not induce the expression of MUC16 mRNA. In the primary cultures of normal nasal epithelial cells, MWCNT also induced the expression of MUC5AC and MUC5B mRNA and the production of MUC5AC and MUC5B proteins.

Conclusion The results of this study demonstrate that MWCNT induces MUC5AC and MUC5B expression in human airway epithelial cells. These findings provide important information about the biological role of MWCNT on mucus-secretion in human airway epithelial cells.

Korean J Otorhinolaryngol-Head Neck Surg 2015;58(8):552-7

Key Words Human airway epithelial cells $\cdot$ MUC5AC $\cdot$ MUC5B $\cdot$ Multi-walled carbon nanotubes.

\section{서 론}

호흡기 상피세포는 점액을 분비하여 기도 내에 적절한 습 도를 유지하며, 외부 물질과 감염원으로부터 기도를 보호한 다. 점액은 물리적 방어벽 역할을 통해 호흡기 상피세포의 직 접적 손상을 막고 점액에 부착된 외부 물질을 섬모운동을 통해 배출시킨다. ${ }^{1,2)}$ 그러나 점액의 과분비는 오히려 감염의 빈도와 기간을 증가시키고 폐기능을 악화시켜 염증성 호흡
기 질환을 유발하는 원인이 된다. 이러한 점액의 물리학적, 생화학적 특성을 결정하는 주요 성분은 고분자 당단백으로 이루어진 점소이다. 점소는 젤 형태를 이루는 분비형과 세포 막에 직접 결합하는 막 부착형으로 나누어진다. 현재까지 약 20개의 점액 유전자가 발견되었고, 이 중 호흡기 점액에서 주 로 발견되는 것은 MUC5AC, MUC5B 분비형 점소와 $\mathrm{MUC1}$, $\mathrm{MUC4}, \mathrm{MUC16}$ 막 부착형 점소이다. ${ }^{1)}$ 그중에서도 점액 바깥 층을 이루는 MUC5AC와 MUC5B 분비형 점소가 생물학적 
으로 중요한 역할을 한다고 알려져 있으며 현재 이에 대한 많 은 연구가 이루어지고 있다. ${ }^{3-6)}$

최근 들어 대기 오염과 환경에 대한 관심이 증가함에 따 라, 사람 호흡기 상피세포에서 점액 분비와 염증 반응을 일 으키는 다양한 환경물질에 대한 연구가 활발히 진행되고 있 다. 점액 분비와 관련된 다양한 환경물질 중 나노 소재는 나 노 공학 기술의 발달로 인해 많은 나노 신소재들이 개발되어 많은 산업 분야에서 사용됨으로써, 호흡기에 직접적으로 노 출되는 기회가 많아지고 있는 실정이다. 따라서 나노 소재가 호흡기에 어떤 영향을 미치는지에 대한 연구도 주목받고 있 다. ${ }^{7-9)}$ 현재 산업 분야에서 가장 많이 사용되는 나노 소재들 중 물리적 강도와 전기적 전도성, 열 전도성이 매우 뛰어난 다중 벽 탄소나노튜브는 탄소입자들이 육각형 고리 모양으로 연결 되어 이루어진 수 나노미터 직경의 튜브 여러 개가 중첩되어 동심원형태를 이룬다. ${ }^{10,11)}$ 최근 동물 실험 연구에 따르면 다 중벽 탄소나노튜브가 호흡기 상피세포의 사이토카인 분비와 염증세포를 증가시켜 알러지 반응과 급성 염증 반응을 일으 킨다고 알려져 있다. ${ }^{12-16)}$ 그러나 호흡기 상피세포에서 점액유 전자 발현과 단백 생성에 어떤 영향을 미치는지에 대한 연구 는 매우 미흡한 실정이다. 따라서 본 연구에서는 다중벽 탄 소나노튜브가 사람 호흡기 상피세포의 점액 유전자의 발현 과 점액 단백 생성에 어떠한 영향을 미치는지 알아보고자 연 구를 시행하였다.

\section{대상 및 방법}

\section{재 료}

다중벽 탄소나노튜브인 CM-95는 Hanhwa Chemical(Seoul, Korea)에서 구입하였고 사람 폐의 점액상피양 암 세포주(human pulmonary mucoepidermoid carcinoma cell line)인 NCIH292 세포는 American Type Culture Collection(Manassas, $\mathrm{VA}, \mathrm{USA}$ )에서 구입하였다. RPMI 1640 배지와 trizol은 Invitrogen(Carlsbad, CA, USA)에서 구입하였고, EpiLife 배지 와 keratinocyte growth supplement는 Cascade Biologics (Portland, OR, USA)에서 구입하였다. Fetal bovine serum (FBS)은 HyClone Laboratories Inc.(Logan, UT, USA)에서 구입하였다. Reverse transcription-polymerase chain reaction(RT-PCR) kits는 Roche Applied Science(Mannheim, Germany)에서 구입하였다.

\section{세포 배양 및 처치}

NCI-H292 세포를 6-well plate에 $1 \times 10^{6}$ cells/well의 농 도로 접종한 후 $2 \mathrm{mM} \mathrm{L}$-glutamine, $100 \mathrm{U} / \mathrm{mL}$ penicillin,
$100 \mu \mathrm{g} / \mathrm{mL}$ streptomycin과 10\% FBS가 포함된 RPMI 1640 배지를 이용하여 $95 \%$ 의 산소와 $5 \%$ 의 이산화탄소가 혼합된 배양기에서 $37^{\circ} \mathrm{C}$ 의 온도로 배양하였다.

다중벽 탄소나노튜브의 효과를 알아보기 위해서 NCI-H292 세포에 $0.01 \mathrm{ug} / \mathrm{mL}$ 와 $0.1 \mathrm{ug} / \mathrm{mL}, 1 \mathrm{ug} / \mathrm{mL}$ 농도의 다중벽 탄소 나노튜브를 각각 투여하였으며, MUC5AC와 MUC5B mRNA 의 발현은 8시간 동안 배양한 후 측정하였고, 단백질의 생성 은 48시간 동안 배양을 시행한 후 추출하여 분석하였다. 처치 용량은 호흡기 상피세포에 대한 다중벽 탄소나노튜브의 세포 독성 실험들을 참고하여 선택하였다. ${ }^{17,18)}$ 대조군은 동일한 시 간 동안 배지에서 NCI-H292 세포를 단독으로 배양하였다.

사람 코점막 상피세포를 얻기 위해서 알레르기에 대한 기저 질환과 가족력이 없고, 피부단자시험과 multiple simultaneous allergen test에서 음성반응이 나온 10명을 대상으로 하여 융 비술을 시행받는 중에 발생하는 비강 내 적출물 중 정상 하비 갑개 조직을 얻었다. 일차배양을 하기 위해 하비갑개 점막조직 을 phosphate-buffered saline(PBS)로 세척한 후, 90분 동안 dispase(Boehringer Mannheim Biochemica, Mannheim, Germany)에 침전시켰다. 외과용 수술칼을 사용하여 하비갑 개 점막의 표면을 벗겨내어, $1 \% \mathrm{PBS}$ 를 추가한 후 mesh를 통 해 여과하였다. 이런 과정을 통해 얻은 하비갑개 점막의 상피세 포들을 24-well $\left(2.5 \times 10^{5}\right.$ cells/well) plate에 접종한 후, EpiLife 배지와 keratinocyte growth supplement $(5 \mathrm{~mL} / 500 \mathrm{~mL}$ of medium)에서 배양하였다. 일차 배양한 코점막 상피세포에서 다중벽 탄소나노튜브의 효과를 알아보기 위해서 세포에 0.01 $\mathrm{ug} / \mathrm{mL}$ 와 $0.1 \mathrm{ug} / \mathrm{mL}, 1 \mathrm{ug} / \mathrm{mL}$ 농도의 다중벽 탄소나노튜브를 각각 투여하였으며, MUC5AC와 MUC5B mRNA의 발현은 8 시간 동안 배양한 후 측정하였고, 단백질의 생성은 48시간 동 안 배양을 시행한 후 추출하여 분석하였다. 대조군은 동일한 시간 동안 배지에서 코점막 상피세포를 단독으로 배양하였다.

실험에서 사용한 NCI-H292 세포와 일차 배양한 코점막 상 피세포에 대한 MWCNT의 세포독성 유무는 MTT 분석(Sigma-Aldrich, St. Louis, MO, USA)과 현미경을 이용한 세포 형 태 변화 유무를 확인하여 검증하였다.

\section{$\mathrm{RT}-\mathrm{PCR}$ 분석}

모든 RNA는 RT-PCR kit(Applied Biosystems, Foster City, $\mathrm{CA}, \mathrm{USA}$ )를 이용하여 동정되었고, GeneAmp RNA PCR cored kit(Applied Bio-systems)를 이용하여 cDNA로 역전 사하였다. 실험에 사용된 primer의 염기서열은 MUC5AC의 경우 sense는 5'-TCA ACG GAG ACT GCG AGT ACA C-3', antisense는 5'-CTT GAT GGC CTT GGA GCA-3'이 고, $\mathrm{MUC5B}$ 의 경우 sense는 5-CAC ATC CAC CCT TCC 
AAC-3', antisense는 5'-GGC TCA TTG TCG TCT CTG-3' 이며, MUC16의 경우 sense는 5'-GCC TCT ACC TTA ACG GTT ACA ATG AA-3', antisense는 5'-GGT ACC CCA TGG CTG TTG TG-3'이다. 각 반응의 내부 양성 대조군은 glyceraldehyde-3-phosphate dehydrogenase (GAPDH)를 사 용하였으며, 염기서열은 sense는 5-CCT CCA AGG AGT AAG ACC CC-3', antisense는 5'-AGG GGT CTA CAT $\mathrm{GGC} \mathrm{AAC} \mathrm{TG}-3$ 이다. 실험에서 사용되어 증폭된 mRNA 산물의 크기는 MUC5AC는 $103 \mathrm{bp}, \mathrm{MUC5B}$ 는 $245 \mathrm{bp}$, MUC16는 $114 \mathrm{bp}, \mathrm{GAPDH}$ 는 $145 \mathrm{bp}$ 였다.

각각의 중합효소연쇄반응 과정을 간략히 설명하면, 배양된 세포를 2\% bovine serum albumin을 함유한 PBS로 3회 세척 한 후 Trizol ${ }^{\circledR}$ (Molecular Research Center, Cincinnati, OH, USA) 을 이용하여 총 mRNA를 추출하였다. MUC5AC mRNA에 대 한 $\mathrm{PCR}$ 은 $95^{\circ} \mathrm{C}$ 에서 60 초간 변성과정과 $60^{\circ} \mathrm{C}$ 에서 60 초간 결합 반응, $72^{\circ} \mathrm{C}$ 에서 60 초간 연장반응을 33 회 반복한 후 $72^{\circ} \mathrm{C}$ 에서 20 분간 최종 연장반응을 시행하였고, MUC5B mRNA에 대 한 $\mathrm{PCR}$ 은 $95^{\circ} \mathrm{C}$ 에서 60 초간 변성과정과 $72^{\circ} \mathrm{C}$ 에서 60 초간 결 합반응, $72^{\circ} \mathrm{C}$ 에서 60 초간 연장반응을 33 회 반복한 후 $72^{\circ} \mathrm{C}$ 에서 20 분간 최종 연장반응을 시행하였으며, MUC16 mRNA에 대 한 $\mathrm{PCR}$ 은 $95^{\circ} \mathrm{C}$ 에서 60 초간 변성과정과 $60^{\circ} \mathrm{C}$ 에서 60 초간 결 합반응, $72^{\circ} \mathrm{C}$ 에서 60 초간 연장반응을 33 회 반복한 후 $72^{\circ} \mathrm{C}$ 에 서 10 분간 최종 연장반응을 시행하였다.

증폭된 중합효소연쇄반응의 산물은 SYBR green이 함유 된 $1 \%$ agarose gel을 통한 전기영동을 이용하여 분리 관찰하 였다. 확인된 띠(band)의 세기는 Scion Image software(Scion Corporation, Frederick, MD, USA)를 이용하여 반정량적으 로 분석하였다. MUC5AC와 MUC5B, MUC16 각각의 띠의 세기는 GAPDH 대조군의 세기와 비교하여 상대적인 값으로 나타내었다.

\section{Real-Time PCR 분석}

합성된 cDNA $1 \mu \mathrm{L}$ 를 대상으로 LC Fast Start DNA Master SYBR Green kit(Roche Applied Science, Mannheim, Germany)를 사용하여 real-time PCR을 이용한 점액 유전자 발현 반응을 시행하였다. Real-time PCR은 최종량이 $10 \mu \mathrm{L}$ 가 되 게 $2.5 \mathrm{mM}$ 의 $\mathrm{MgCl}_{2}$ 와 최종 농도가 $0.5 \mu \mathrm{M}$ 이 되게 primer를 투여하였으며, $25 \mathrm{ng}$ 의 RNA $1 \mu \mathrm{L}$ 를 이용하여 실험을 수행하 였다. 정량적인 PCR은 Light-Cycler(Roche Applied Science, Mannheim, Germany)를 사용하여 $95^{\circ} \mathrm{C}$ 에서 10 초간 변성과 정을 거치고 $60^{\circ} \mathrm{C}$ 에서 5 초간 결합반응을 시킨 후, $72^{\circ} \mathrm{C}$ 에서 10 초간 연장반응하였고, 이러한 과정을 45 회 반복하였다. 증폭 의 정확도는 변성곡선(melting curve, Roche Applied Science,
Mannheim, Germany)을 사용하여 평가하였다.

\section{면역분석법(Immunoassay)}

$\mathrm{MUC5AC}$ 와 MUC5B의 점액 단백의 함량을 측정하기 위 해서 enzyme-linked immunosorbent assay(ELISA) 법을 이 용하였다. 시료를 처리한 배양된 세포에서 lysis buffer[50 mM Tris-HCl(pH 7.5), 1 mM ethylene glycol tetraacetic acid, 1\% Triton X-100, and $1 \mathrm{mM}$ phenylmethylsulfonyl fluoride]로 단백을 추출하여 정량화하였다. 추출한 단백 $100 \mu \mathrm{g}$ 을 96well plate에 담고 $40^{\circ} \mathrm{C}$ 에서 건조될 때까지 방치한 후 plate를 $\mathrm{PBS}$ 로 3회 세척하였다. 비특이적 결합을 방지하기 위해 $2 \%$ bovine serum albumin으로 실온에서 1 시간 동안 차단한 후 $\mathrm{PBS}$ 로 3회 세척한 다음 $0.05 \%$ Tween 20을 함유한 PBS에 1:200으로 희석된 MUC5AC와 MUC5B 일차항체로 반응시 켰다. 다시 PBS로 3 회 세척한 후 horseradish peroxidaseconjugated 이차항체를 $0.05 \%$ Tween 20를 함유한 PBS에 1:5000으로 희석하여 각 well에 첨가하였고, 1 시간 후에 각 well을 PBS로 3회 세척하였다. 3,3,5,5'-tetramethyl benzidine 용액으로 발색한 후, $2 \mathrm{~N}-\mathrm{H}_{2} \mathrm{SO}_{4}$ 를 이용하여 중단시켰다. ELISA reader(EL800 ${ }^{\circledR}$, BIO-TEK Instruments, Winooski, VT, USA) 로 $450 \mathrm{~nm}$ 에서 흡광도를 측정한 후 표준곡선을 이용하여 단 백의 양을 정량화하였다.

\section{통 계}

통계 처리는 Windows용 SPSS version 10.0(SPSS Inc., Chic$\mathrm{ago}, \mathrm{IL}, \mathrm{USA})$ 을 사용하였다. 모든 실험은 $p$ 값이 0.05 미만인 경우를 유의한 것으로 정하여 Student's t-test를 이용하였다.

\section{결 과}

\section{$\mathrm{NCI}-\mathrm{H} 292$ 세포에서 다중벽 탄소나노튜브가 MUC5AC와 MUC5B mRNA 발현에 미치는 영향}

다중벽 탄소나노튜브가 MUC16과 MUC5AC, MUC5B 각 각의 발현에 미치는 영향을 알아보기 위해 NCI-H292 세포 에 다중벽 탄소나노튜브 $(0.01,0.1,1 \mathrm{ug} / \mathrm{mL})$ 를 투여하여 8시 간 동안 배양 후 RT-PCR을 시행하였다. 실험 결과상 다중 벽 탄소나노튜브는 MUC5AC mRNA와 MUC5B mRNA 발 현을 통계적으로 유의하게 증가시키지만, MUC16 mRNA 발 현의 유의한 증가는 없었다(Fig. 1A).

\section{NCI-H292 세포에서 다중벽 탄소나노튜브가 시간에 따 라 MUC5AC와 MUC5B mRNA 발현에 미치는 영향}

시간에 따라 다중벽 탄소나노튜브가 MUC5AC와 MUC5B 
각각의 발현에 미치는 영향을 알아보기 위해 NCI-H292 세포 에 다중벽 탄소나노튜브를 $0.1 \mathrm{ug} / \mathrm{mL}$ 농도로 투여하여 2, 4, 8,24 시간 동안 배양 후 real-time PCR을 시행하였다. 실험 결 과상 다중벽 탄소나노튜브는 시간에 따라 MUC5AC mRNA
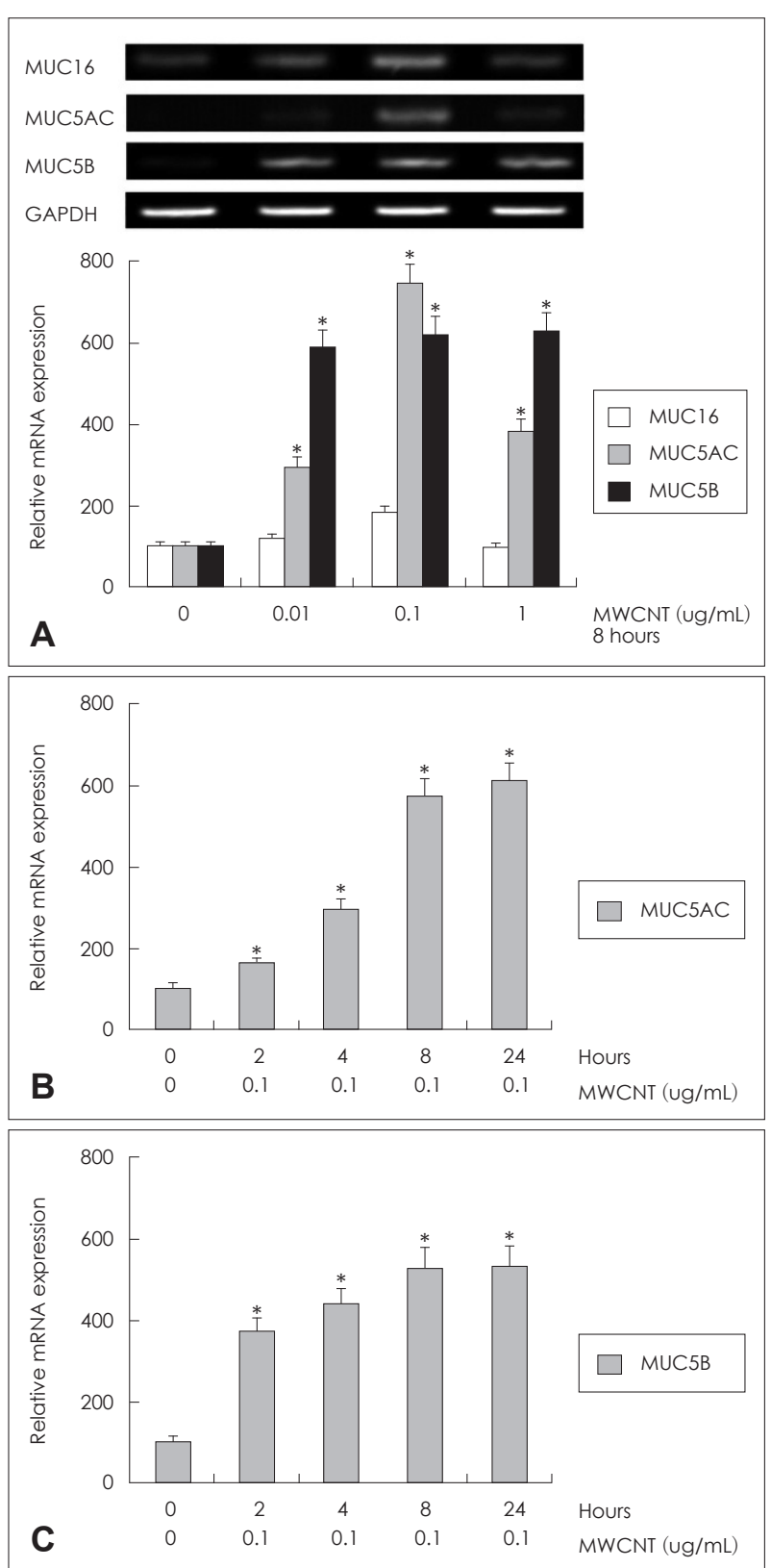

Fig. 1. Effects of MWCNT on mucin expression in human NClH292 cells. RT-PCR showed that MWCNT significantly induced MUC5AC and MUC5B mRNA expression at 8 hours after exposure of MWCNT. However, MWCNT did not increase MUC16 mRNA expression (A). Real-time PCR showed that the MWCNTinduced MUC5AC and MUC5B mRNA expression were increased at all times (B and $C)$. The images are representative of three separate experiments performed in triplicated. Bars indicate the mean \pm S.D. of three independent experiments performed in triplicate. ${ }^{*} p<0.05$ compared with zero value. MWCNT: multi walled carbon nanotubes, RT-PCR: reverse transcription polymerase chain reaction.
와 MUC5B mRNA 발현을 통계적으로 유의하게 증가시켰 다(Fig. $1 \mathrm{~B}$ and $\mathrm{C}$ ).

\section{$\mathrm{NCI}-\mathrm{H} 292$ 세포에서 다중벽 탄소나노튜브가 MUC5AC와} MUC5B 단백 생성에 미치는 영향

다중벽 탄소나노튜브가 MUC5AC, MUC5B 단백 형성에 미치는 영향을 알아보기 위해 NCI-H292 세포에 다중벽 탄 소나노튜브 $(0.01,0.1,1 \mathrm{ug} / \mathrm{mL})$ 를 투여하여 48시간 동안 배 양한 후 ELISA법을 시행하였다. 실험 결과상 다중벽 탄소나 노튜브는 MUC5AC 단백과 MUC5B 단백 생성을 통계적으 로 유의하게 증가시켰다(Fig. 2).

\section{사람 코점막 상피세포에서 다중벽 탄소나노튜브가 \\ MUC5AC와 MUC5B mRNA 발현에 미치는 영향}

다중벽 탄소나노튜브가 사람 코점막 상피세포에서 MU$\mathrm{C} 5 \mathrm{AC}$ 와 MUC5B 발현에 미치는 영향을 알아보기 위해 사람 코점막 상피세포를 일차 배양 후 다중벽 탄소나노튜브 $(0.01$, $0.1,1 \mathrm{ug} / \mathrm{mL}$ )를 투여하여 8시간 동안 배양 후 RT-PCR을 시행하였다. 실험 결과상 사람 코점막 상피세포에서 다중벽
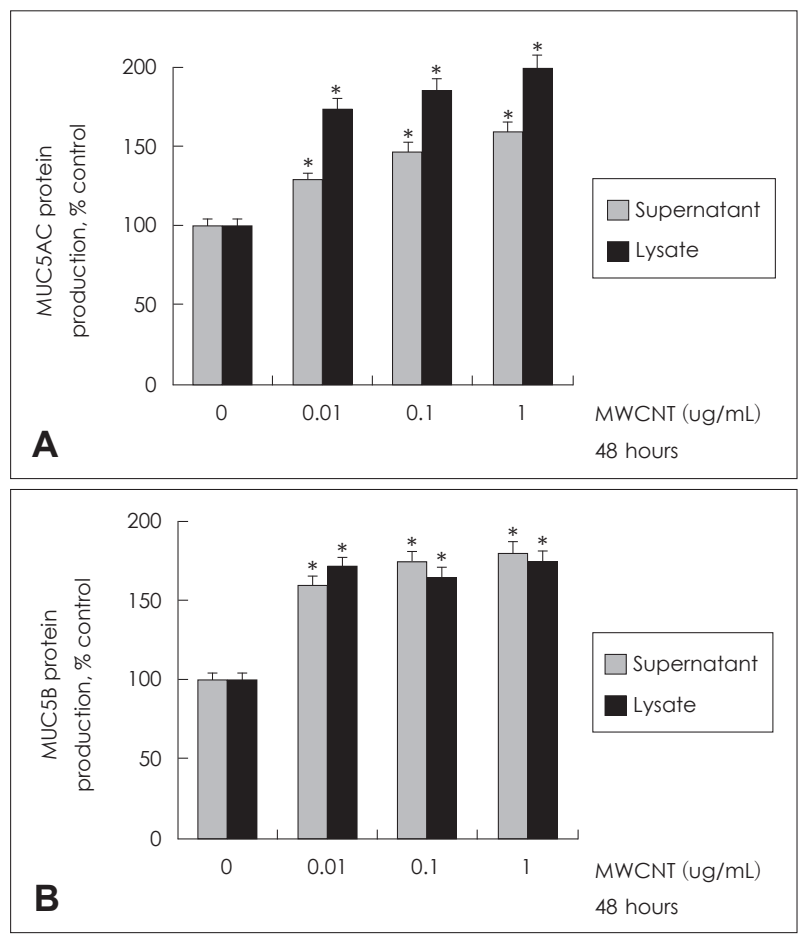

Fig. 2. Effects of MWCNT on MUC5AC and MUC5B protein production in human $\mathrm{NCl}-\mathrm{H} 292$ cells. ELISA showed that MWCNT significantly increased MUC5AC and MUC5B protein production at 48 hours after exposure of MWCNT. The images are representative of three separate experiments performed in triplicated. Bars indicate the mean \pm S.D. of three independent experiments performed in triplicate $(\mathrm{A}$ and $\mathrm{B}) .{ }^{*} p<0.05$ compared with zero value. MWCNT: multi walled carbon nanotubes, ELISA: enzyme-linked immunosorbent assay. 
탄소나노튜브가 MUC5AC mRNA와 MUC5B mRNA 발현 을 통계적으로 유의하게 증가시켰다(Fig. 3A).

\section{사람 코점막 상피세포에서 다중벽 탄소나노튜브가 MUC5AC와 MUC5B 단백 생성에 미치는 영향}

다중벽 탄소나노튜브가 MUC5AC, MUC5B 단백 형성에
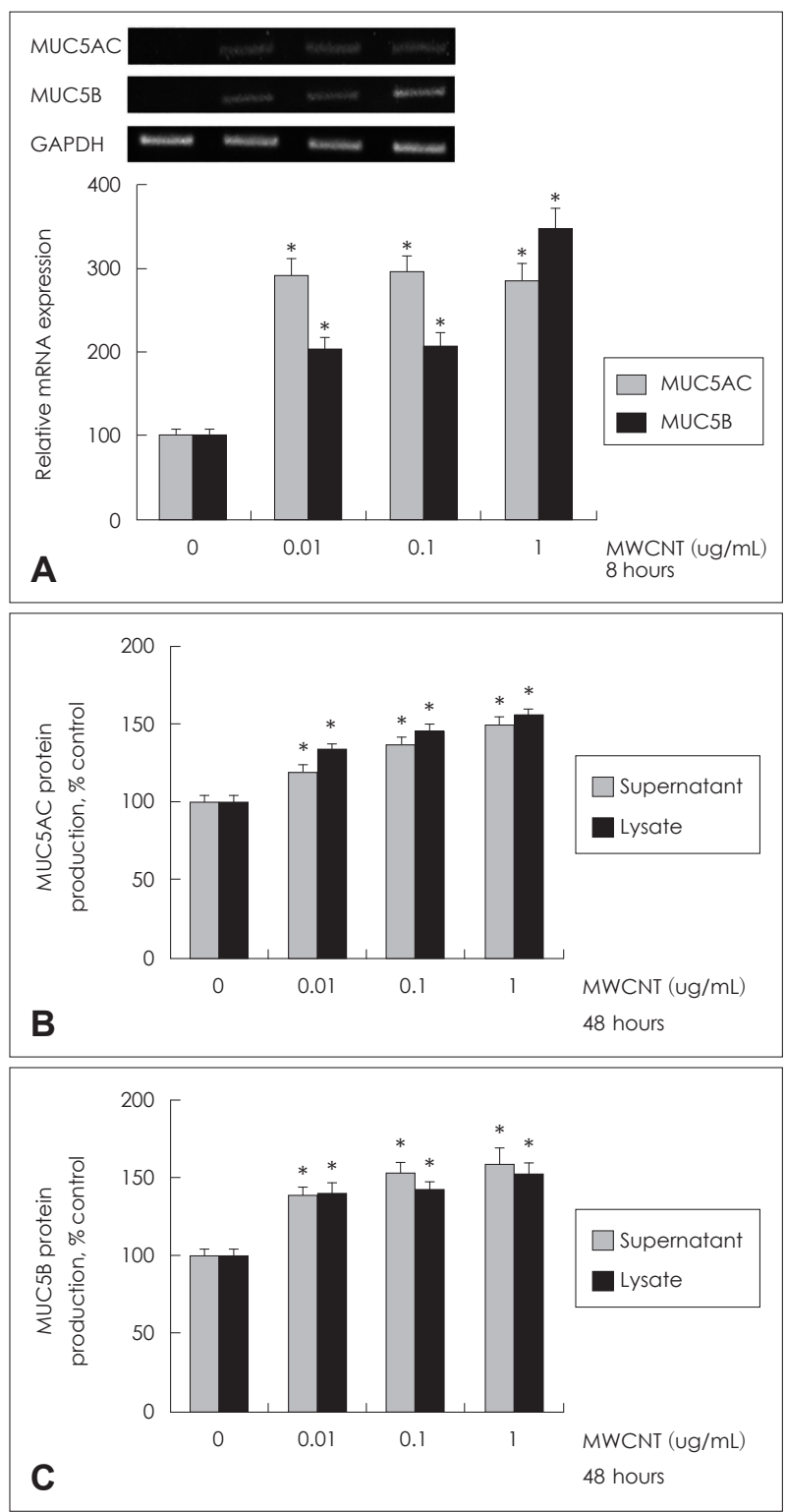

Fig. 3. Effects of MWCNT on MUC5AC and MUC5B mRNA expression and protein production in human nasal epithelial cells. RT-PCR showed that MWCNT significantly induced MUC5AC and MUC5B mRNA expression at 8 hours after exposure of MWCNT (A). ELISA showed that MWCNT significantly increased MUC5AC and MUC5B protein production at 48 hours after exposure of MWCNT (B and C). The images are representative of three separate experiments performed in triplicated. Bars indicate the mean \pm S.D. of three independent experiments performed in triplicate. ${ }^{*} p<0.05$ compared with zero value. MWCNT: multi walled carbon nanotubes, RT-PCR: reverse transcription polymerase chain reaction, ELISA: enzyme-linked immunosorbent assay.
미치는 영향을 알아보기 위해 사람 코점막 상피세포에서 다 중벽 탄소나노튜브 $(0.01,0.1,1 \mathrm{ug} / \mathrm{mL})$ 를 투여하여 48시간 동 안 배양한 후 ELISA법을 시행하였다. 실험 결과상 다중벽 탄 소나노튜브는 MUC5AC 단백과 MUC5B 단백 생성을 통계적 으로 유의하게 증가시켰다(Fig. 3B and C).

\section{고 찰}

다중벽 탄소나노튜브는 강철보다 5배 가벼우면서도 15 20배 우수한 기계적 강도와 뛰어난 전기적 전도성과 높은 내열성으 로 인해 많은 복합 재료와 에너지 저장 물질, 화학 센서, 코팅 제로 사용되고 있으며, 미래에는 항공 우주 산업과 의료 산업 까지 다양하게 활용될 것으로 전망되고 있다. ${ }^{10)}$ 이와 같은 나 노 물질의 산업적 용도와 활용 가능성으로 인해 나노 물질이 인체 노출에 미치는 영향에 대한 관심 역시 높아지고 있다.

최근 연구에 따르면 다중벽 탄소나노튜브를 쥐에 흡인시킨 후 기관지 폐포 세척액을 분석하였을 때 다형핵백혈구가 증가 하였고, 무세포 기관지 폐포 세척액에서는 총 단백의 양과 lactate dehydrogenase, tumor necrosis factor-alpha, interleukin(IL)-1 beta, 점소의 분비, surfactant protein-D가 증가되 면서, 쥐의 기관지 조직에 다형핵백혈구와 단핵구가 침윤되고 배상세포도 증가된 소견을 보였다. ${ }^{14)}$ 천식 모델 쥐를 이용한 연구에 따르면 다중벽 탄소나노튜브와 집먼지 진드기를 비강 내 점적하면 대식세포와 호산구, 중성구, 림프구, transforming growth factor-beta 1, 점소의 분비, IL-13, IL-25, IL-33, thymic stromal lymphopoietin, granulocyte-macrophage colony-stimulating factor가 집먼지 진드기를 단독으로 비강 내 점적했을 경우보다 의미 있게 더 증가하였다. ${ }^{13)}$ 또한, platelet-derived growth factor가 활성화됨에 따라 기관지 조직 내의 collagen 침착과 이로 인한 섬유화가 유발됨이 확인되었다. ${ }^{13,15)}$

위와 같이 다중벽 탄소나노튜브를 이용한 동물 실험을 통 해 염증세포와 염증 매개물질, 점소 등의 증가와 이로 인한 호 흡기 염증과의 연관성이 알려져 있으나, 사람 호흡기 상피세포 에서 다중벽 탄소나노튜브가 중요 점액 유전자들의 발현에는 어떠한 영향을 미치는지는 아직까지 명확하게 밝혀지지 않았 다. 본 연구에서는 NCI-H292 세포와 사람 코점막 상피세포에 서 다중벽 탄소나노튜브를 투여하여 배양한 후, 호흡기 상피세 포에서 가장 중요한 역할을 담당하는 분비형 점소인 MUC5AC 와 MUC5B 발현이 증가함을 확인하였으며, 이 결과들은 사람 호흡기 상피세포에서 다중벽 탄소나노튜브가 점액의 과분비 에 관여하는 생물학적 기능을 가짐을 확인할 수 있다. 그러나, 막결합형 점소인 MUC16의 발현에는 영향을 미치지 않았다, 이는 다중벽 탄소나노튜브가 호흡기 점소의 종류나 형태에 따 
라 다르게 영향을 미친다는 것을 확인할 수 있는 부분으로, 이 러한 차이에 대한 명확한 이해를 위해 호흡기 점소의 기능과 조절 기전에 대한 보다 심도 있는 연구가 필요하다고 생각된다.

탄소 나노튜브가 염증 반응에 있어 호흡기 상피세포에 작용 하는 세포 내 기전에 대한 연구에 의하면, scavenger receptor 등과 결합하여 세포 내로 들어온 탄소나노튜브 입자가 세포 내 활성산소의 증가를 유발하며, 이로 인해 mitogen-activated protein kinase와 nuclear factor kappa-light-chain-enhancer of activated B cells, activator protein-1, protein serine-threonine kinase 등의 하위 신호 전달 체계가 활성화되어 염증 반 응이 유발된다는 사실이 알려져 있다. ${ }^{19,20)}$ 본 연구에서는 다중 벽 탄소나노튜브에 의한 MUC5AC와 MUC5B 발현에 작용 하는 세포 내 기전에 대한 연구가 이루어지지 않아서 신호 전 달 체계는 알 수가 없었지만, MUC5AC와 MUC5B 발현의 신 호 전달 체계 중 이미 많이 보고되고 있는 mitogen-activated protein kinase 신호 전달 체계가 관여할 것으로 추정된다. ${ }^{21,22)}$ 따라서 다중벽 탄소나노튜브가 사람 호흡기 상피세포에서 점 액 유전자 발현에 미치는 영향을 보다 자세하게 이해하기 위 해서는 점액 유전자 발현에 관계되는 신호 전달 체계에 대한 연 구와 더불어 실험 동물을 이용한 연구가 반드시 필요할 것으로 생각된다.

본 연구 결과를 통해 다중벽 탄소나노튜브가 사람 호흡기 상피세포에서 점액의 과분비에 관여함을 알 수 있었고, 이는 사람 호흡기에서 나노 소재의 생물학적 기능 중 점액 과분비에 대한 연구의 중요한 기초 자료로 활용될 것으로 생각된다.

\section{REFERENCES}

1) Ali MS, Pearson JP. Upper airway mucin gene expression: a review. Laryngoscope 2007;117(5):932-8.

2) Kim KC. Role of epithelial mucins during airway infection. Pulm Pharmacol Ther 2012;25(6):415-9.

3) Lee JH, Kim GO, Na HG, Park NK, Kim HS, Kim JK, et al. Effect of anthocyanidin on MUC5AC and MUC5B expression in airway epithelial cells. Korean J Otorhinolaryngol-Head Neck Surg 2013;56 (5):291-6.

4) Park NK, Choi YS, Lee JH, Kim HS, Kim JK, Ahn JH, et al. Effect of udenafil on MUC5B expression in human airway epithelial cells. Korean J Otorhinolaryngol-Head Neck Surg 2013;56(8):501-5.

5) Lee JG, Moon HJ, Kim SS, Kim CW, Yoon JH. Expression and regulation of MUC8 \& MUC5AC by various cytokines in normal human nasal epithelial cells. Korean J Otolaryngol-Head Neck Surg 2001;44(6):600-5.

6) Song EJ, Bae CH, Kim JY, Kim YW, Park SY, Song SY, et al. Effect of epigallocatechin-3-gallate on PMA-induced MUC5B expression in human airway epithelial cells. Clin Exp Otorhinolaryngol 2013;6 (4):237-42.

7) Colvin VL. The potential environmental impact of engineered nanomaterials. Nat Biotechnol 2003;21(10):1166-70.

8) Demou E, Peter P, Hellweg S. Exposure to manufactured nanostructured particles in an industrial pilot plant. Ann Occup Hyg 2008;52(8):695-706.

9) Aillon KL, Xie Y, El-Gendy N, Berkland CJ, Forrest ML. Effects of nanomaterial physicochemical properties on in vivo toxicity. Adv Drug Deliv Rev 2009;61(6):457-66.

10) Ajayan PM. Nanotubes from Carbon. Chem Rev 1999;99(7):1787-800.

11) Andrews R, Jacques $D$, Qian $D$, Rantell $T$. Multiwall carbon nanotubes: synthesis and application. Acc Chem Res 2002;35(12):1008-17.

12) Han SG, Andrews R, Gairola CG. Acute pulmonary response of mice to multi-wall carbon nanotubes. Inhal Toxicol 2010;22(4):340-7.

13) Ronzani C, Casset A, Pons F. Exposure to multi-walled carbon nanotubes results in aggravation of airway inflammation and remodeling and in increased production of epithelium-derived innate cytokines in a mouse model of asthma. Arch Toxicol 2014;88(2):489-99.

14) Inoue $K$, Koike $E$, Yanagisawa R, Hirano $S$, Nishikawa M, Takano H. Effects of multi-walled carbon nanotubes on a murine allergic airway inflammation model. Toxicol Appl Pharmacol 2009;237(3):306-16.

15) Ryman-Rasmussen JP, Tewksbury EW, Moss OR, Cesta MF, Wong $\mathrm{BA}$, Bonner JC. Inhaled multiwalled carbon nanotubes potentiate airway fibrosis in murine allergic asthma. Am J Respir Cell Mol Biol 2009; 40(3):349-58.

16) Hussain S, Vanoirbeek JA, Luyts K, De Vooght V, Verbeken E, Thomassen LC, et al. Lung exposure to nanoparticles modulates an asthmatic response in a mouse model. Eur Respir J 2011;37(2):299-309.

17) Visalli G, Bertuccio MP, Iannazzo D, Piperno A, Pistone A, Di Pietro A. Toxicological assessment of multi-walled carbon nanotubes on A549 human lung epithelial cells. Toxicol In Vitro 2015;29(2):352-62.

18) Ju L, Zhang G, Zhang X, Jia Z, Gao X, Jiang Y, et al. Proteomic analysis of cellular response induced by multi-walled carbon nanotubes exposure in A549 cells. PLoS One 2014;9(1):e84974.

19) Jiang C, Jia J, Zhai S. Mechanistic understanding of toxicity from nanocatalysts. Int J Mol Sci 2014;15(8):13967-92.

20) Snyder-Talkington BN, Pacurari M, Dong C, Leonard SS, Schwegler-Berry D, Castranova V, et al. Systematic analysis of multiwalled carbon nanotube-induced cellular signaling and gene expression in human small airway epithelial cells. Toxicol Sci 2013; 133(1):79-89.

21) Bae CH, Kwak DS, Ye SB, Song SY, Kim YD. Diallyl disulfide induces MUC5B expression via ERK2 in human airway epithelial cells. Phytother Res 2012;26(2):197-203.

22) Woo HJ, Yoo WJ, Bae CH, Song SY, Kim YW, Park SY, et al. Leptin up-regulates MUC5B expression in human airway epithelial cells via mitogen-activated protein kinase pathway. Exp Lung Res 2010; 36(5):262-9. 